\title{
Degradation of trichloroethene by a linear- plasmid-encoded alkene monooxygenase in Rhodococcus corallinus (Nocardia corallina) B-276
}

\author{
Hisashi Saeki, ${ }^{2}$ Miura Akira, ${ }^{2}$ Keizo Furuhashi, ${ }^{2}$ Beate Averhoff' \\ and Gerhard Gottschalk'
}

Author for correspondence: Beate Averhoff. Tel: +49551 394041. Fax: +49551393793. e-mail: BAVERHO@gwdg.de

1 Institut für Mikrobiologie und Genetik, GeorgAugust-Universität, Grisebachstrasse 8,

D-37077 Göttingen, Germany

2 Pharmaceuticals and Biotechnology Laboratory. Japan Energy Co. Ltd 3-17-35, Niizo-Minami, Toda-shi, Shaitama 335, Japan
Rhodococcus corallinus (formerly Nocardia corallina) B-276, isolated with propene as sole carbon and energy source, is able to oxidize trichloroethene (TCE). Glucose- or propene-grown R. corallinus B-276 cells exhibited no difference in TCE degradation efficiency. TCE degradation was found to be growth-phase-dependent and maximum rates were monitored with stationaryphase cells. $K_{m}$ and $V_{\max }$ values for TCE degradation of $R$. corallinus B-276 grown in nutrient broth medium in the presence of glucose were $187 \mu \mathrm{M}$ and $2.4 \mathrm{nmol}$ min $^{-1}$ (mg protein) ${ }^{-1}$, respectively. Escherichia coli recombinants harbouring and expressing the alkene monooxygenase genes of $R$. corallinus B-276 exhibited the ability to degrade TCE. This result provides clear evidence that the alkene monooxygenase of $R$. corallinus B-276 catalyses TCE oxidation. $R$. corallinus B-276 was shown to contain four linear plasmids, pNC10 (70 kb), pNC20 (85 kb), pNC30 (185 kb) and pNC40 (235 kb). The observation that pNC30-deficient strains had lost the ability to grow on propene suggested that the genes of the propene degradation pathway are encoded by the linear plasmid pNC30. Southern blot analysis with cloned alkene monooxygenase genes from $R$. corallinus B-276 revealed a positive hybridization signal with the linear plasmid pNC30. This result clearly shows that the alkene monooxygenase is encoded by the linear plasmid pNC30. Eleven short-chainalkene-oxidizing strains were screened for the presence of linear plasmids. Among these, four propene-oxidizing Rhodococcus strains and one etheneoxidizing Mycobacterium strain were found to contain linear megaplasmids. Southern blot analysis with the alkene monooxygenase revealed positive signals with linear plasmids of two propene-oxidizing Rhodococcus ruber strains. These results indicate that homologous alkene monooxygenases are encoded by linear plasmids in $R$. ruber strains.

Keywords: Rhodococcus corallinus (Nocardia corallina) B-276, alkene monooxygenase, trichloroethene cooxidation, linear plasmids

\section{INTRODUCTION}

Trichloroethene (TCE) is an extensively used industrial solvent and due to its broad application and high volatility it has become a major ground water con-
Abbreviations: CHEFE, contour-clamped homogeneous electric field electrophoresis; TCE, trichloroethene. taminant. Since TCE is a potential health hazard, intensive efforts have been undertaken to analyse microbial TCE degradation and to develop appropriate bioremediation processes (Ensley, 1991). Several organisms have been shown to degrade TCE via nonspecific catabolic oxygenases, such as methane monooxygenase of methanotrophs (Brusseau et al., 1990; Fox et al., 1990; Harker \& Kim, 1990; Koh et al., 1993; Oldenhuis et al., 1989; Tsien et al., 1989), ammonia 
monooxygenase of Nitrosomonas europaea (Arciero et al., 1989; Vannelli et al., 1990), toluene 2-monooxygenase of Burkholderia (formerly Pseudomonas) cepacia G4 (Newman \& Wackett, 1997; Shields et al., 1989), toluene 3-monooxygenase of Ralstonia (formerly Pseudomonas) pickettii PKO1 (Kaphammer et al., 1990), toluene 4-monooxygenase of Pseudomonas mendocina KR1 (Winter et al., 1989), toluene 2,3-dioxygenase of Pseudomonas putida F1 (Wackett \& Gibson, 1988; Zylstra et al., 1989), phenol hydroxylase of Alcaligenes eutrophus JMP134 (Kim et al., 1996), alkene monooxygenase of Xanthobacter Py2 (Ensign et al., 1992), isopropylbenzene dioxygenase of Pseudomonas sp. JR1 and Rhodococcus erythropolis BD2 (Dabrock et al., 1992; Kesseler et al., 1996) and propane monooxygenase of Mycobacterium vaccae JOB5 (Wackett et al., 1989).

Alkene monooxygenases catalyse the epoxidation of short-chain alkenes to their corresponding epoxides as the initial step in the utilization of aliphatic alkenes. The multicomponent alkene monooxygenase system of Xanthobacter Py2, which has been purified and characterized in some detail (Small \& Ensign, 1997), has undergone intensive investigations with respect to degradation of chlorinated alkenes (Ensign et al., 1992; Ensign, 1996).

Rhodococcus corallinus (formerly Nocardia corallina) B-276, which was isolated with propene as sole carbon and energy source, also initiates the oxidation of alkenes to the corresponding epoxides by an alkene monooxygenase (EC 1.14.13.-) (Furuhashi, 1992). The alkene monooxygenase of this strain, which has been purified and characterized, shows fundamental differences to the enzyme system of Xanthobacter Py2 (Miura $\&$ Dalton, 1995). The enzyme system of $R$. corallinus B276 comprises three components: an epoxygenase, a $\mathrm{NADH}$ reductase and a coupling protein. The epoxygenase consists of two different subunits, a 53 and a $35 \mathrm{kDa}$ subunit, and contains approximately $2 \mathrm{~mol} \mathrm{non-}$ haem iron per mol protein. The reductase is an ironsulfur flavoprotein of $40 \mathrm{kDa}$ which is responsible for the transfer of reducing equivalents from NADH to the epoxygenase. The coupling protein is a single-subunit protein of $14 \mathrm{kDa}$ not containing any prosthetic groups and appears to function as a regulator of activity (Miura \& Dalton, 1995). Since the epoxygenase is considered to be the catalytic component of this enzyme system, its physico-chemical features have been closely investigated, leading to a proposal for the mechanism of stereospecific epoxidation by the alkene monooxygenase in $R$. corallinus B-276 (Gallagher et al., 1997, 1998). Recently, Gallagher et al. (1997) showed that the alkene monooxygenase from $R$. corallinus B-276 is also a member of the class of monooxygenases containing a diiron centre motif at the active site. Two conserved Glu$\mathrm{X}-\mathrm{X}-\mathrm{His}$ domains, which provide the protein-derived ligands to the di-iron centres in the soluble methane monooxygenase, were found in each of these large oxygenase subunits (Saeki \& Furuhashi, 1994).

We cloned and sequenced the genes encoding the alkene monooxygenase from $R$. corallinus B-276 (Saeki \& Furuhashi, 1994). These studies revealed that the alkene monooxygenase genes are clustered in the order amoA, $a m o B, a m o C, a m o D$, and encode the small subunit of the epoxygenase, the coupling protein, the large subunit of the epoxygenase and the reductase, respectively. A comparison of the amino acid sequence of AmoC with the amino acid sequence of the methane monooxygenase (MmoX) of Methylococcus capsulatus (Bath) revealed the presence of two conserved Glu-X-X-His motifs suggested to act as iron cluster ligands, thus participating in a hydrogen-bonding network. Based on the conservation of these amino acids, we proposed that the alkene monooxygenase contains binuclear iron centres, and this was confirmed by the results gained from electromagnetic resonance spectral analysis of the purified epoxygenase component (Gallagher et al., 1997).

In this study, we report on the identification of the alkene monooxygenase in $R$. corallinus B-276 as the TCE-oxidizing enzyme system. TCE degradation was found to be inducer-independent but growth-phasedependent. We describe the identification of linear plasmids in $R$. corallinus B-276 and provide clear evidence that the alkene monooxygenase is encoded by the linear plasmid $\mathrm{pNC} 30$.

\section{METHODS}

Bacterial strains and growth conditions. $R$. corallinus B-276 was previously isolated from soil (Furuhashi et al., 1981). The 15 different variants $(R$. corallinus $\mathrm{B}-276.101-\mathrm{B}-276.115)$ used in this study were obtained after growth with NBG broth containing $2.8 \%(\mathrm{w} / \mathrm{v}$ ) nutrient broth no. 2 (Oxoid) and $1.0 \%$ $(\mathrm{w} / \mathrm{v})$ glucose at $30^{\circ} \mathrm{C}$ under nonselective conditions. $R$. corallinus B-276 cells were grown in mineral medium (M3) containing (per litre) $1.0 \mathrm{~g} \mathrm{NH}_{4} \mathrm{NO}_{3}, 0.82 \mathrm{~g} \mathrm{MgSO}_{4} .7 \mathrm{H}_{2} \mathrm{O}$, $1.87 \mathrm{~g} \mathrm{KH}_{2} \mathrm{PO}_{4}, 6.4 \mathrm{~g} \mathrm{Na}_{2} \mathrm{HPO}_{4} .2 \mathrm{H}_{2} \mathrm{O}, 1 \mathrm{ml}$ trace element solution (Tschech \& Pfennig, 1984) and $1 \mathrm{ml}$ vitamin solution (Claus et al., 1983). Propene as a source of carbon was supplied via the gas phase. Incubation in M3 or NBG media was carried out at $30^{\circ} \mathrm{C}$. Cultures were grown either in shake flasks or in sealed shake flasks with propene $(10 \%, \mathrm{v} / \mathrm{v})$ supplied via the gas phase. E. coli JM109(pSTT100) and JM109(pUC18) were grown in Luria-Bertani (LB) medium supplemented with $50 \mu \mathrm{g}$ ampicillin $\mathrm{ml}^{-1}$ at $37^{\circ} \mathrm{C}$. To induce the transcription of the alkene monooxygenase genes from the lac promoter, IPTG was added to a final concentration of $1.0 \mathrm{mM}$ after $4.5 \mathrm{~h}$ incubation and cells were further incubated for $3 \mathrm{~h}$. The strains used in this study are listed in Table 1.

Degradation of chlorinated hydrocarbons. The $R$. corallinus B-276 cells were harvested by centrifugation at 8000 r.p.m. for $10 \mathrm{~min}$ at $4{ }^{\circ} \mathrm{C}$, washed once and resuspended in reaction buffer (per litre deionized water: $\mathrm{K}_{2} \mathrm{HPO}_{4}, 1.74 \mathrm{~g}$; $\mathrm{MgSO}_{4} .7 \mathrm{H}_{2} \mathrm{O}, 1.5 \mathrm{~g} ; \mathrm{FeSO}_{4} .7 \mathrm{H}_{2} \mathrm{O}, 50 \mathrm{mg} ; \mathrm{pH} 7 \cdot 5$ ). Cell suspensions $(5 \mathrm{ml})$ were transferred to $152 \mathrm{ml}$ glass serum bottles sealed with Teflon-lined Mininert Valves (Dynatech). To perform TCE degradation experiments with recombinant E. coli strains, the cells were grown at $37^{\circ} \mathrm{C}$ in $400 \mathrm{ml} \mathrm{LB}$ medium with $1 \%$ glucose in the presence of $50 \mathrm{mg}$ ampicillin $\mathrm{ml}^{-1}$. IPTG was added to a final concentration of $1 \mathrm{mM}$ after $4.5 \mathrm{~h}$ of growth. After further incubation for $2.5 \mathrm{~h}$, the cells were harvested, washed and resuspended in $40 \mathrm{ml}$ reaction buffer. The degradation experiments were started by the 
Table 1. Bacterial strains used in this study

\begin{tabular}{|c|c|c|c|}
\hline Strain & $\begin{array}{l}\text { Relevant } \\
\text { properties* }\end{array}$ & $\begin{array}{l}\text { Size of linear } \\
\text { plasmids }(\mathbf{k b}) \dagger\end{array}$ & Source or reference \\
\hline Escherichia coli JM109(pSTT100) & $a m o A B C D, \mathrm{Ap}^{\mathrm{r}}$ & NA & Saeki \& Furuhashi (1994) \\
\hline Escherichia coli JM109(pUC18) & $A p^{r}$ & NA & Yanisch-Perron et al. (1985) \\
\hline Rhodococcus corallinus B- 276 & Wild-type, $\mathrm{PRO}^{+}$ & $70,85,185,235$ & Furuhashi et al. (1981) \\
\hline \multicolumn{4}{|l|}{$\begin{array}{l}\text { Spontaneous mutants of Rhodococcus } \\
\text { corallinus B- } 276\end{array}$} \\
\hline B-276.101 & $\mathrm{PRO}^{-}$ & $70,85,235$ & \multirow{15}{*}{ This study } \\
\hline B-276.102 & $\mathrm{PRO}^{-}$ & $70,85,100,235$ & \\
\hline B-276.103 & $\mathrm{PRO}^{-}$ & $70,85,235$ & \\
\hline B-276.104 & $\mathrm{PRO}^{-}$ & $70,85,235$ & \\
\hline B-276.105 & $\mathrm{PRO}^{-}$ & $70,85,235$ & \\
\hline B-276.106 & $\mathrm{PRO}^{-}$ & $70,85,235,250$ & \\
\hline B-276.107 & $\mathrm{PRO}^{-}$ & $70,85,235$ & \\
\hline B-276.108 & $\mathrm{PRO}^{-}$ & $70,85,235$ & \\
\hline B- 276.109 & $\mathrm{PRO}^{-}$ & $70,85,235$ & \\
\hline B-276.110 & $\mathrm{PRO}^{-}$ & $70,85,235$ & \\
\hline B-276.111 & $\mathrm{PRO}^{-}$ & $70,85,235$ & \\
\hline B-276.112 & $\mathrm{PRO}^{-}$ & $70,85,235,290$ & \\
\hline B-276.113 & $\mathrm{PRO}^{-}$ & $70,85,235$ & \\
\hline B-276.114 & $\mathrm{PRO}^{-}$ & $70,85,235$ & \\
\hline B-276.115 & $\mathrm{PRO}^{-}$ & $70,85,95,235$ & \\
\hline Rhodococcus thodochrous P-3-28 & $\mathrm{PRO}^{+}$ & 70,230 & \multirow{11}{*}{ K. Furuhashi (unpublished) } \\
\hline Rhodococcus rbodochrous P-3-101-1 & $\mathrm{PRO}^{+}$ & $70,85,230$ & \\
\hline Rhodococcus ruber P-IV-B-11 & $\mathrm{PRO}^{+}$ & 260 & \\
\hline Rbodococcus ruber $\mathrm{P}-\mathrm{V}-\mathrm{B}-171$ & $\mathrm{PRO}^{+}$ & 70,260 & \\
\hline Rhodococcus fascians $\mathrm{B}-2-2$ & $\mathrm{BUT}^{+}$ & ND & \\
\hline Rhodococcus fascians B-2-25 & $\mathrm{BUT}^{+}$ & ND & \\
\hline Rbodococcus fascians B-3-36-3 & $\mathrm{BUT}^{+}$ & ND & \\
\hline Mycobacterium sp. E-2-1 & $\mathrm{ETH}^{+}$ & ND & \\
\hline Mycobacterium sp. E-2-47 & $\mathrm{ETH}^{+}$ & ND & \\
\hline Mycobacterium sp. E-1-35 & $\mathrm{ETH}^{+}$ & ND & \\
\hline Mycobacterium sp. E-1-57 & $\mathrm{ETH}^{+}$ & 260,340 & \\
\hline Rhodococcus erythropolis $\mathrm{BD} 2$ & $\mathrm{IPB}^{+}$ & 208 & \multirow{2}{*}{ Dabrock et al. (1994) } \\
\hline Rhodococcus erythropolis BD2.101 & $\mathrm{IPB}^{-}$ & ND & \\
\hline
\end{tabular}

NA, Not analysed.

ND, None detected.

" $\mathrm{PRO}^{+}$, propene-oxidizing character; $\mathrm{BUT}^{+}, 1,3$-butadiene-oxidizing character; $\mathrm{ETH}^{+}$, ethene-oxidizing character; $\mathrm{IPB}^{+}$, isopropylbenzene-oxidizing character.

$\dagger$ All sizes are approximate.

addition of substrates. TCE and other chlorinated hydrocarbon stock solutions were prepared in completely filled vials by dissolving them in $N, N$-dimethylformamide (DMF). Glucose solution $(10 \% ; 250 \mu \mathrm{l})$ was added to the cell suspensions before adding TCE. No more than $5 \mu$ l stock solutions of chlorinated hydrocarbons per $5 \mathrm{ml}$ cell suspension were added to avoid undesired side-effects of DMF. The bottles were incubated in a water bath at $30^{\circ} \mathrm{C}$ with reciprocal shaking at 150 r.p.m. TCE degradation was quantified by headspace gas chromatography as described recently (Berendes et al., 1998). All data given reflect the results of experiments in duplicate bottles. To determine the $K_{\mathrm{m}}$ values, the actual TCE concentration in the liquid phase was calculated using a Henry's constant of 0.5 at $30^{\circ} \mathrm{C}$ (Amoore \& Hautala, 1983). The kinetic parameters for TCE degradation, $V_{\max }$ and $K_{m}$, were determined from the Lineweaver-Burk plot assuming that TCE degradation follows Michaelis-Menten kinetics. The protein content was measured by the method of Schmidt et al. (1963).

Degradation of propene. Propene degradation experiments were conducted analogously to the TCE degradation studies (column temperature for $\mathrm{GC}$ was changed to $200^{\circ} \mathrm{C}$ ). Propene 
was supplied via the gas phase. To determine the $K_{\mathrm{m}}$ values, the actual propene concentration in the liquid phase was calculated from the Bunsen coefficient for propene at $30^{\circ} \mathrm{C}$ (Wilhelm et al., 1977). Kinetic parameters for propene degradation, $V_{\max }$ and $K_{m}$, were determined from the Lineweaver-Burk plot assuming that propene degradation follows Michaelis-Menten kinetics.

DNA manipulation. DNA manipulations were performed as described by Sambrook et al. (1989).

Preparation of DNA for detection of linear plasmids. Cultures of bacterial strains were grown for $24-48 \mathrm{~h}$ at $30^{\circ} \mathrm{C}$ in $\mathrm{LB}$ medium supplemented with $1 \%$ glucose and $1 \%$ (w/v) glycine. Samples $(0.35 \mathrm{ml})$ of the cultures were centrifuged at 8000 r.p.m. and resuspended in $0.25 \mathrm{ml}$ EET [0.1 M EDTA, $10 \mathrm{mM}$ ethylene glycol-bis( $\beta$-aminoethyl ether) $-N, N, N^{\prime}, N^{\prime}$ tetraacetic acid, $10 \mathrm{mM}$ Tris $/ \mathrm{HCl}, \mathrm{pH} 8 \cdot 0]$ and then mixed with $0.75 \mathrm{ml} 2.0 \%(\mathrm{w} / \mathrm{v})$ low-melting-point agarose at $40^{\circ} \mathrm{C}$ to prepare agarose plugs. The resulting plugs were incubated in TE buffer ( $50 \mathrm{mM}$ Tris, $20 \mathrm{mM}$ EDTA; pH 8.0) containing lysozyme ( $2 \mathrm{mg} \mathrm{ml}^{-1}$ ), Achromobacter lyticus peptidase $(2 \mathrm{mg}$ $\mathrm{ml}^{-1}$ ) (Wako Pure Chemicals) and sodium $N$-lauroylsarcosine $\left(0.5 \mathrm{mg} \mathrm{ml}^{-1}\right)$ for $4 \mathrm{~h}$ at $30^{\circ} \mathrm{C}$ and then treated at $55^{\circ} \mathrm{C}$ overnight in EET buffer containing $1 \%(\mathrm{w} / \mathrm{v})$ SDS. The plugs were washed in TE buffer for $2 \mathrm{~h}$ and finally stored in TE buffer at $4{ }^{\circ} \mathrm{C}$ until they were used for contour-clamped homogeneous electric field electrophoresis (CHEFE).

CHEFE. This was performed by using a Pulsaphor system obtained from Pharmacia. It was carried out at $15^{\circ} \mathrm{C}$ with a switching interval of $10-20 \mathrm{~s}$ for $17 \mathrm{~h}$ or $10-40 \mathrm{~s}$ for $15 \mathrm{~h}$ at $170 \mathrm{~V}$ in $0.5 \times$ TBE $(44.5 \mathrm{mM}$ Tris, $44.5 \mathrm{mM}$ borate, $1 \mathrm{mM}$ EDTA; pH 8.5) using a $0.8 \%$ agarose gel. DNA bands were stained with ethidium bromide and visualized by means of a UV-transilluminator. Size determinations of linear plasmids were performed by the use of concatemers of $\lambda$ DNA as highmolecular-mass DNA standards (Anand, 1986; Matthew et al., 1988).

Southern hybridization. After CHEFE separation, DNA was transferred to nylon membranes (GeneScreen Plus; Dupont, NEN Research Products) using a vacuum blotting system. The amoABC-specific DNA probe (a $1.8-\mathrm{kb}$ PstI-NotI DNA fragment derived from pSTT100) was treated with a digoxigenin-dUTP DNA labelling kit (Boehringer Mannheim). Hybridization reactions and subsequent detection with a DIG luminescent detection kit (Boehringer Mannheim) were performed according to the manufacturer's protocol. Hybridization reactions were performed at $55^{\circ} \mathrm{C}$ and the filters were washed twice with $0.5 \times \mathrm{SSC}(1 \times \mathrm{SSC}$ is $0.15 \mathrm{M} \mathrm{NaCl}$, $0.015 \mathrm{M}$ sodium citrate) $/ 0.1 \%$ SDS for $30 \mathrm{~min}$ and once with $0 \cdot 1 \times \mathrm{SSC} / 0 \cdot 1 \% \mathrm{SDS}$ for $10 \mathrm{~min}$ at $55^{\circ} \mathrm{C}$.

\section{RESULTS}

\section{Trichloroethene degradation by $R$. corallinus B-276}

A propene-grown culture of $R$. corallinus B-276 was harvested after $72 \mathrm{~h}$ to study the TCE degradation of resting cells. The ability of strain B-276 to degrade TCE is depicted in Fig. 1(a). Immediately after the addition of TCE, the cells started TCE oxidation. No TCE degradation was detected in a control experiment without cells. To analyse the growth-substrate dependence of TCE oxidation, the TCE degradation of NBG-grown resting cells of strain B-276 was monitored. As depicted in Fig. 1(b), growth of strain B-276 with glucose led to TCE oxidation rates comparable to those obtained with propene-grown cells. Twenty-five per cent of the initial amount of TCE was degraded within $6 \mathrm{~h}$ of incubation.

\section{Growth-phase dependence of TCE degradation by $R$. corallinus B-276}

Studies on growth-phase-dependent alkene monooxygenase activity in $R$. corallinus B276 have been performed by Miura (1993) and Furuhashi et al. (1981). These studies clearly showed that the alkene monooxygenase activity is induced after $24 \mathrm{~h}$ growth on glucose during the onset of stationary phase. In order to evaluate the effect of growth phase on TCE degradation, we monitored the TCE degradation rates of lateexponential-phase cells ( $24 \mathrm{~h}$ growth) and stationaryphase cells (48, 72 or $96 \mathrm{~h}$ growth). The growth-phase dependence of TCE degradation is obvious from the data in Fig. 1(b). With late-exponential-phase cells, no TCE degradation was found during the first $6 \mathrm{~h}$ of incubation, whereas stationary-phase cells started to oxidize TCE immediately after addition of TCE. No difference in TCE degradation efficiency was detected with resting cells of B-276 cultures grown for 48,72 and $96 \mathrm{~h}$, respectively (Fig. 1b). Further incubation of the late-exponential-phase cells for more than $6 \mathrm{~h}$ led to an increased TCE oxidation capability $35 \%$ of the TCE supplied was degraded between 6 and $23 \mathrm{~h}$ of incubation). The immediate TCE degradation of B-276 stationary-phase cells together with the correlating results of Miura (1993) showing that alkene monooxygenase is induced after glucose has been consumed, indicate that the expression of the alkene monooxygenase might be controlled by catabolite repression.

\section{Kinetics of TCE and propene degradation}

The initial TCE degradation rates by $R$. corallinus B-276 were studied with respect to different TCE concentrations (data not shown). The actual TCE concentration in the liquid phase $(30-200 \mathrm{mM}$ ) was calculated using a TCE gas/water partition coefficient (concentration in air/concentration in water) of 0.5 at $30^{\circ} \mathrm{C}$ (Amoore \& Hautala, 1983). The initial TCE degradation rates were determined for the first hour. $V_{\max }$ and $K_{\mathrm{m}}$ values calculated from the initial TCE degradation rates during the first hour of incubation were $2.4 \mathrm{nmol}$ $\min ^{-1}$ (mg protein) ${ }^{-1}$ and $187 \mu \mathrm{M}$, respectively. The kinetics of propene degradation were also studied. Taking into consideration the partitioning of propene between the gas and liquid phase by means of the published Bunsen coefficients for gases (Wilhelm et al., 1977 ), $V_{\max }$ and $K_{\mathrm{m}}$ values of propene degradation were calculated to be $59 \mathrm{nmol} \mathrm{m^{-1 }}$ (mg protein) ${ }^{-1}$ and $16.0 \mu \mathrm{M}$, respectively. Taken together, these results show that the maximum degradation rate and the affinity of the alkene monooxygenase of $R$. corallinus B276 for propene are significantly higher than those for TCE. 

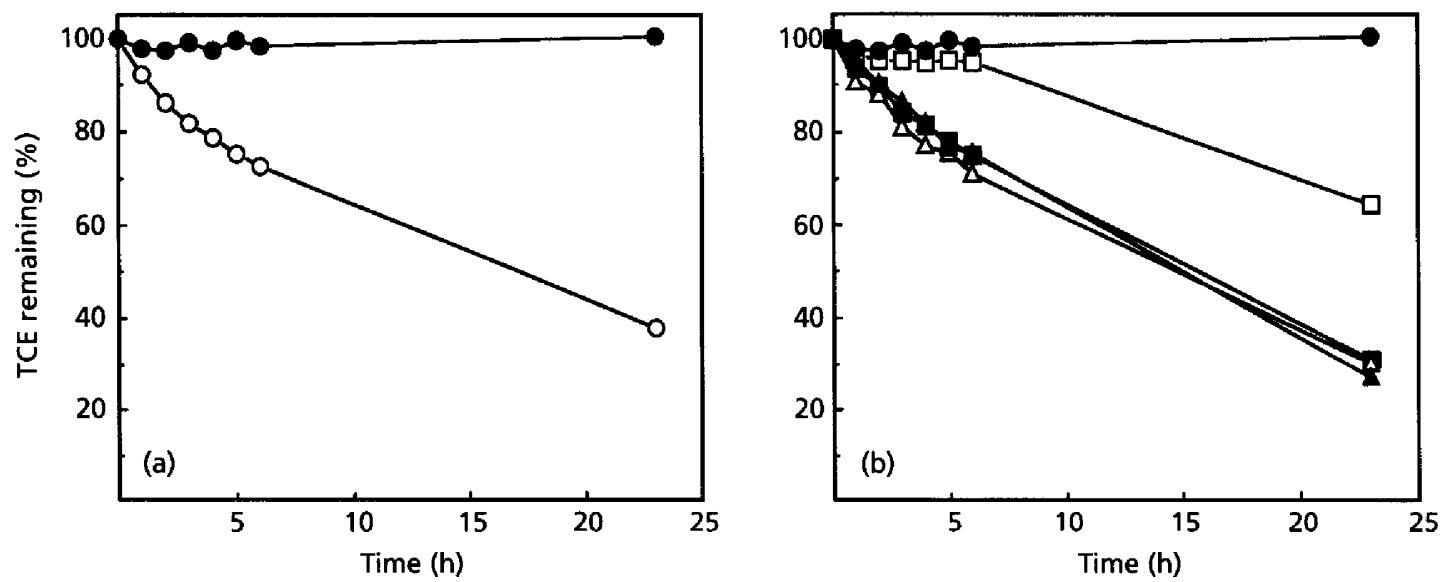

Fig. 1. Extent of TCE degradation by $R$. corallinus $B-276$. The assays were performed with resting cells $\left(O D_{600} 5 \cdot 0\right)$ in the presence of $5 \mathrm{mmol}$ TCE. (a) $O$, Cells grown on $M 3$ (propene) for $72 \mathrm{~h}$;, abiotic control. (b) $\square, \square, \triangle, \Delta$, Cells grown on NBG for 24, 48, 72 and $96 \mathrm{~h}$, respectively;, abiotic control.

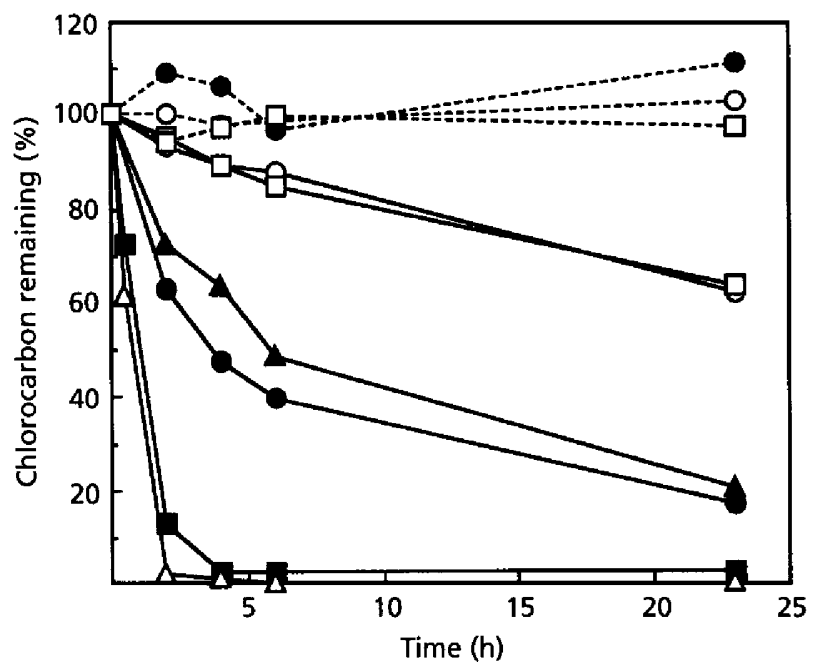

Fig. 2. Time course of the degradation of chlorinated solvents by resting cells of $R$. corallinus B-276. The assays were performed in the presence of $2 \mathrm{mmol}$ chlorinated solvent with NBG-grown cells $\left(O D_{600} 5 \cdot 0\right)$ as described in Methods. Symbols on solid lines: $O$, TCE; $\bigcirc, 1,1$-dichloroethene; $\square$, trans1,2-dichloroethene; $\mathbf{\square}$, cis-1,2-dichloroethene; $\triangle$, 2,3dichloropropene; $\boldsymbol{\Delta}, 1,3$-dichloropropene. Symbols on broken lines: $O$, dichloromethane; 0 , 1,2-dichloromethane; $\square$, chloroform.

\section{Substrate specificity of the alkene monooxygenase}

Cell suspensions of $R$. corallinus B-276 were tested for their ability to degrade different chlorinated compounds. As depicted in Fig. 2, the resting cells started to degrade TCE, 1,1-dichloroethene, trans-1,2-dichloroethene, cis1,2-dichloroethene, 2,3-dichloropropene and 1,3-dichloropropene immediately after the addition of the corresponding chlorocarbon compound. Among the chlorinated alkenes degraded, cis-1,2-dichloroethene and 2,3-dichloropropene were almost completely consumed within $4 \mathrm{~h} ; 83 \%$ of 1,1-dichloroethene and $81 \%$ of 1,3-dichloropropene were degraded within $23 \mathrm{~h}$ of incubation, whilst only about $38 \%$ of TCE and $37 \%$ of trans-1,2-dichloroethene were degraded within $23 \mathrm{~h}$ of incubation. Chlorinated alkanes, including dichloromethane, 1,2-dichloroethane and chloroform, were not converted by strain B-276. As shown by studies with a spontaneous mutant $R$. corallinus B-276.101, the loss of the ability to grow on propene correlated with the loss of the ability to degrade chlorinated alkenes.

\section{Alkene-monooxygenase-mediated TCE degradation by recombinant $E$. coli JM109 cells}

By analogy with the alkene monooxygenase of Xanthobacter Py 2 , we suggested that the alkene monooxygenase in strain B-276 was responsible for the cooxidation of TCE. To address this question, the TCE degradation of the recombinant strain E. coli JM109(pSTT100), which contains the structural genes of the alkene monooxygenase of $R$. corallinus B-276 under the control of the lac promoter, was investigated. The expression of the alkene monooxygenase genes in $E$. coli JM109(pSTT100) in response to the addition of IPTG has already been shown by Saeki \& Furuhashi (1994). TCE degradation studies of recombinant $E$. coli strains revealed that $35 \%$ of the total TCE supplied was degraded by the alkene-monooxygenase-carrying strain E. coli JM109(pSTT100) after 16 h of incubation. No TCE degradation was found in the controls, such as with heat-killed $E$. coli cells and recombinant $E$. coli cells carrying pUC18. These results strongly suggest that the alkene monooxygenase of $R$. corallinus B-276 is mediating TCE oxidation.

\section{Detection of linear megaplasmids in $\boldsymbol{R}$. corallinus B-276}

When we examined the propene degradation of $R$. corallinus B-276, we observed a spontaneous instability of the propene-oxidizing phenotype $\left(\mathrm{PRO}^{+}\right)$. Revertants from $\mathrm{PRO}^{-}$to $\mathrm{PRO}^{+}$were not observed. These results 


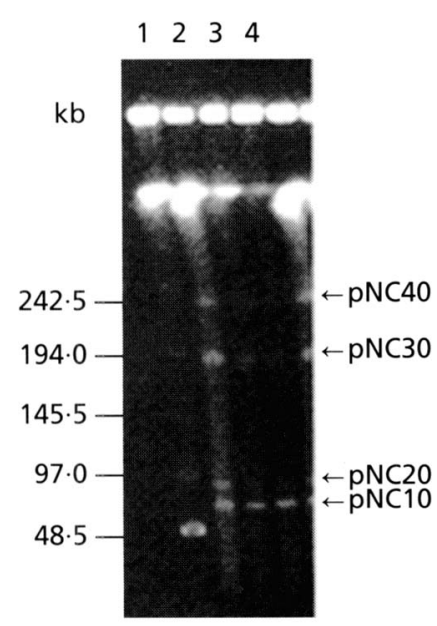

Fig. 3. Detection of linear DNA molecules from $R$. corallinus B276 by CHEFE. CHEFE was carried out at $170 \mathrm{~V}$ for $17 \mathrm{~h}$ with 10-20 s pulse times. Lanes: $1, \lambda$ ladder; $2-4$, agarose-embedded B-276 DNA treated with lysis buffer containing (per $\mathrm{ml} \mathrm{TE}$ buffer) $2.0 \mathrm{mg}$ lysozyme, $0.5 \mathrm{mg} \mathrm{N}$-lauroylsarcosine and $2 \mathrm{mg}$ (lane 2), $1 \mathrm{mg}$ (lane 3) or $0.5 \mathrm{mg}$ (lane 4) A. lyticus peptidase.

strongly suggest that the genes responsible for propene degradation of $R$. corallinus B-276 are localized on a mobile DNA element. Recent studies revealed that large linear plasmids of nocardioform actinomycetes are involved in catabolic functions including oxygenases such as isopropylbenzene dioxygenase (Dabrock et al., 1994) and biphenyl dioxygenase (Masai et al., 1997). To analyse the propene-oxidizing wild-type strain B-276 for linear plasmids, we performed CHEFE with agaroseembedded lysed B-276 cells. These analyses led to the identification of four different linear plasmids named pNC10 $(70 \mathrm{~kb}), \mathrm{pNC} 20(85 \mathrm{~kb}), \mathrm{pNC} 30(185 \mathrm{~kb})$ and pNC40 (235 kb) (Fig. 3, lane 2). To confirm the linear topology of these plasmids, separate gels were run with different pulse times. During CHEFE, the extent of migration of circular molecules relative to linear molecules varies considerably according to pulse times (Saeki \& Furuhashi, 1994). All four plasmids were confirmed to be linear based on the relative migration positions compared to the reference $\lambda$ ladder at different pulse times (data not shown). When the concentration of A. lyticus peptidase in the lysis buffer was reduced from 2 to 1 or $0.5 \mathrm{mg} \mathrm{ml}^{-1}$, three of the four linear plasmids, pNC20, pNC30 and pNC40, became nondetectable (Fig. 3). The detection of pNC10 remained unaffected.

\section{Analysis of linear plasmids in spontaneous mutants which had lost the ability to grow on propene}

A total of fifteen spontaneous mutants which had lost the ability to grow on propene ( $\mathrm{PRO}^{-}$variants) (Table 1) were analysed by CHEFE for the presence of linear plasmids. All mutants lacked plasmid pNC30 (Fig. 4a). This observation strongly suggests that either part or even the complete propene degradation pathway is
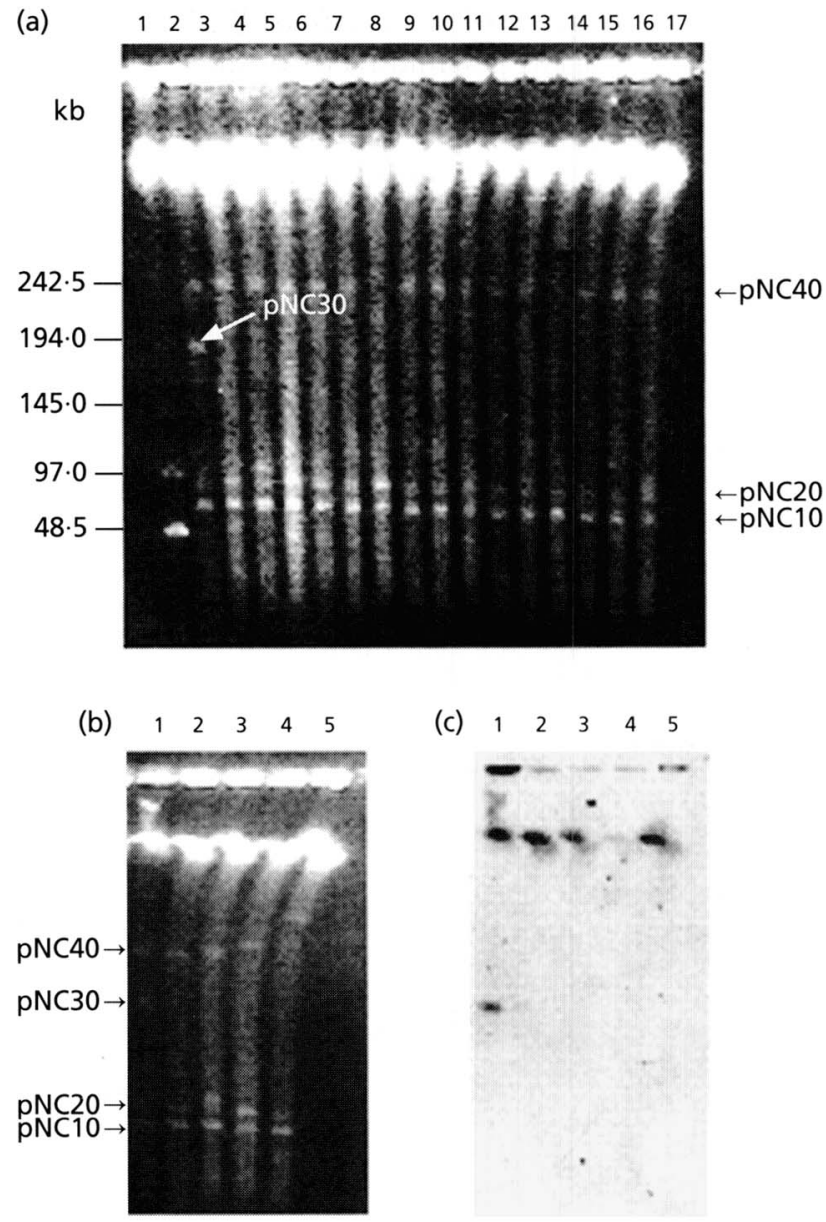

(c) $\begin{array}{lllll}1 & 2 & 3 & 4 & 5\end{array}$

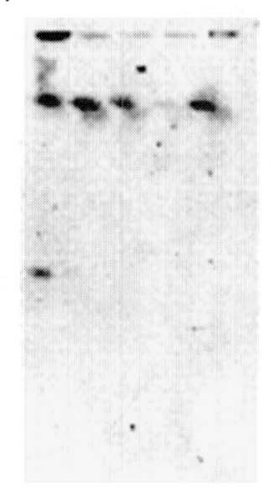

Fig. 4. Detection of linear DNA molecules in $R$. corallinus strains. (a) CHEFE analysis of $R$. corallinus B-276 and spontaneous mutants which had lost the ability to grow on propene; $(b, c)$ Southern blot analysis using the DIG-labelled $1.8 \mathrm{~kb}$ Pstl-Notl fragment of plasmid pSTT100 carrying the alkene monooxygenase genes of $R$. corallinus B-276. CHEFE was carried out at $170 \mathrm{~V}$ for $17 \mathrm{~h}$ with $10-20 \mathrm{~s}$ pulse times. (a) Lanes: $1, \lambda$ ladder; $2, R$. corallinus B-276; $3-17, R$. corallinus B276.101 to $\mathrm{B}-276.115$. (b, c) Lanes: $1, R$. corallinus $\mathrm{B}-276 ; 2, R$. corallinus B-276.101; 3 , R. corallinus B-276.102; 4, R. corallinus $\mathrm{B}-276.106 ; 5, R$. corallinus $\mathrm{B}-276.112$.

encoded by the linear plasmid pNC30. Among the $\mathrm{PRO}^{-}$ variants, two strains contained an additional linear plasmid of smaller size and two other strains contained an additional linear plasmid of larger size with a simultaneous loss of pNC40 (Table 1, Fig. 4a). The linear plasmid of smaller size is most probably a deletion derivative of $\mathrm{pNC} 30$ ( $\mathrm{pNC} 30 \Delta)$, and the linear plasmid of larger size might be a recombinant plasmid of $\mathrm{pNC} 30 \Delta$ and $\mathrm{pNC} 40$.

\section{Localization of the alkene monooxygenase genes on the linear plasmid pNC30}

To analyse the localization of the alkene monooxygenase genes, a Southern hybridization was performed with a $1.8 \mathrm{~kb}$ Pst $\mathrm{I}-\mathrm{Not} \mathrm{I}$ fragment carrying alkene 
monooxygenase genes of $R$. corallinus B-276. For these hybridizations, linear plasmid DNA of the $\mathrm{PRO}^{+} \mathrm{B}-276$ wild-type strain, of the spontaneous $\mathrm{PRO}^{-}$mutant $\mathrm{B}-$ 276.101 and of three other spontaneous $\mathrm{PRO}^{-}$mutants, B-276.102, B-276.106 and B-276.112, which contain additional large or small plasmids, was used. The hybridization profile observed with undigested linear plasmid DNA revealed hybridization signals with a $185 \mathrm{~kb}$ linear DNA fragment and with the chromosomal DNA. The $185 \mathrm{~kb}$ signal corresponds to pNC30 (Fig. $4 \mathrm{~b}, \mathrm{c})$. No signals were detected with PstI-digested total DNA isolated from $\mathrm{PRO}^{-}$mutants devoid of pNC30 (data not shown). The lack of any hybridization signal of the alkene monooxygenase genes with DNA from the $\mathrm{PRO}^{-}$mutant suggests that the signals with the main bacterial chromosome (Fig. 4c) result from unspecific hybridizations due to very high amounts of chromosomal DNA separated in the CHEFE gels. These results, together with the $\mathrm{PRO}^{-}$phenotype of the pNC30 mutant, provide clear evidence that the alkene monooxygenase genes are located on the linear plasmid pNC30. Further analysis of $\mathrm{PRO}^{-}$variants revealed that these variants had also lost the capacity to degrade propene oxide, which is an intermediate of propene degradation (data not shown). These results suggest that in addition to the alkene monooxygenase the linear plasmid pNC30 encodes enzymes implicated in the further breakdown of the propene oxide produced from propene by the alkene monooxygenase in $R$. corallinus B-276.

\section{Survey of linear plasmids from short-chain-alkene- oxidizing strains}

Stock cultures able to grow on either ethene, propene or 1,3-butadiene have been isolated from various soil samples employing conventional enrichment and isolation techniques. Among the strains isolated with propene as sole source of carbon, four showed the ability to epoxidize propene after growth in NBG medium. These strains were identified by the National Collection of Industrial and Marine Bacteria (Aberdeen, UK) as Rhodococcus rhodochrous P-3-28, P-3-101-1, Rhodococcus ruber P-IV-B-11 and P-V-B-171 (Table 1). The strains isolated with ethene or 1,3-butadiene showed either no ability to epoxidize propene after growth in NBG medium or were not able to grow in this medium. Three of the strains isolated with 1,3-butadiene were identified as Rhodococcus fascians B-2-2, B-2-25 and B-3-36-3, whereas the four ethene-oxidizing strains, found to be members of the genus Mycobacterium, were designated Mycobacterium sp. E-2-1, E-2-47, E-1-35 and E-1-57.

The newly isolated strains were analysed for the presence of linear plasmids. All propene-oxidizing strains and one ethene-oxidizing strain were found to contain linear plasmids of different sizes (Table 1). These findings support the suggestion that linear plasmids are broadly distributed in a wide range of actinomycetes. (a)

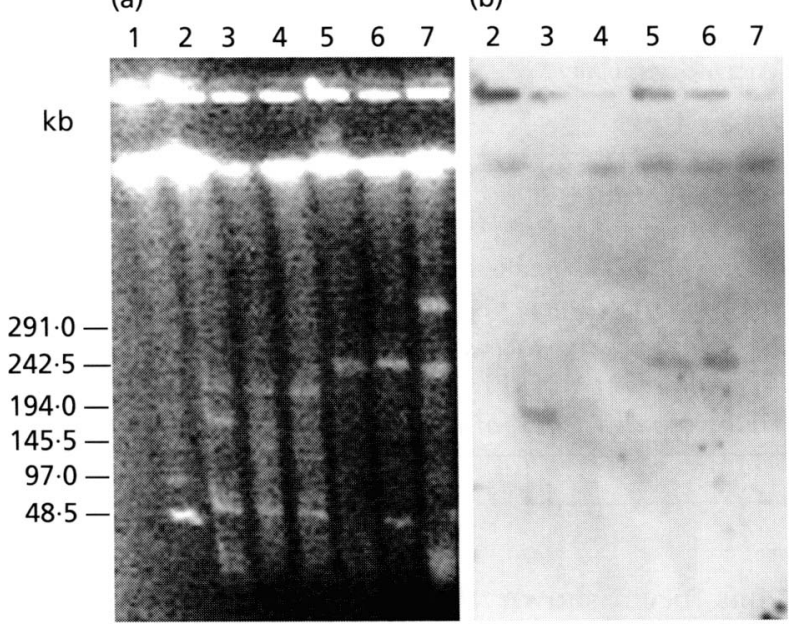

Fig. 5. Linear DNA molecules in lysed cells of propene-oxidizing Rhodococcus strains and an ethene-oxidizing Mycobacterium strain by CHEFE and Southern blot analysis. (a) CHEFE was carried out at $170 \mathrm{~V}$ for $15 \mathrm{~h}$ with $10-40 \mathrm{~s}$ pulse times; (b) a DIGlabelled $1.8 \mathrm{~kb}$ Pst-Notl fragment of plasmid pSTT100 carrying alkene monooxygenase genes of $R$. corallinus B-276 was used as probe. Lanes: $1, \lambda$ ladder; $2, R$. corallinus B-276; $3, R$. rhodochrous $\mathrm{P}-3-28 ; 4$, $R$. rhodochrous $\mathrm{P}-3-101-1 ; 5$, $R$. ruber $\mathrm{P}-$ IV-B-11; 6, R. ruber P-V-B-171; 7, Mycobacterium sp. E-1-57.

\section{Distribution of plasmid-borne alkene monooxygenases in different Rhodococcus species}

To analyse the distribution of linear plasmids carrying alkene monooxygenase genes, Southern hybridizations were performed using an amo $A B C$ probe (the $1.8 \mathrm{~kb}$ Pstl-NotI fragment from pSTT100). These studies revealed that the alkene monooxygenase genes from strain B-276 hybridized to the $260 \mathrm{~kb}$ linear plasmids of the propene-oxidizing strains $R$. ruber P-IV-B-11 and PV-B-171 (Fig. 5b). These results suggest the presence of similar alkene monooxygenase genes on these linear plasmids of the two $R$. ruber strains.

\section{DISCUSSION}

In this study, we report on the TCE degradation of the alkene monooxygenase from $R$. corallinus B-276 and provide clear evidence that the alkene monooxygenase of strain B-276 is located on a linear megaplasmid. To our knowledge, this is the first report of the detection of a linear plasmid encoding alkene degradation.

With the exception of $N$. europaea, TCE-degrading wild-type strains require the addition of exogenous inducer substrates for induction of TCE-cooxidizing oxygenases (Ensley, 1991). Usually, physiological substrates of such oxygenases serve as inducer substrates, although there have been reports of TCE-mediated induction of TCE-cooxidizing toluene mono- or dioxygenases in Pseudomonas strains (McClay et al., 1995; Leahy et al., 1996; Shingleton et al., 1998). Furthermore, 
Table 2. Kinetic parameters of TCE degradation by different monooxygenases

\begin{tabular}{|c|c|c|c|c|c|}
\hline Micro-organism & Enzyme & $\begin{array}{l}\text { Growth } \\
\text { substrate }\end{array}$ & $\begin{array}{c}V_{\max }\left[\text { nmol min }{ }^{-1}\right. \\
\left.(\text { mg protein })^{-1}\right]\end{array}$ & $\begin{array}{c}\boldsymbol{K}_{\mathrm{m}} \\
(\boldsymbol{\mu M})\end{array}$ & Reference \\
\hline Rhodococcus corallinus B-276 & Alkene monooxygenase & NBG medium & $2 \cdot 4$ & 187 & This study \\
\hline Xanthobacter sp. Py 2 & Alkene monooxygenase & Propene & 16 & 116 & Reij et al. (1995) \\
\hline Burkholderia cepacia G4 & Toluene 2-monooxygenase & Phenol & 9 & 4 & Sun \& Wood (1996) \\
\hline Burkholderia cepacia G4 PR1 & Toluene 2-monooxygenase & LB medium & 18 & 29 & Sun \& Wood (1996) \\
\hline Pseudomonas mendocina $\mathrm{KR} 1$ & Toluene 3-monooxygenase & Phenol & 20 & 10 & Sun \& Wood (1996) \\
\hline Pseudomonas putida $\mathrm{F} 1$ & Toluene dioxygenase & Toluene & 8 & 5 & Sun \& Wood (1996) \\
\hline Metbylosinus trichosporium $\mathrm{OB} 3 \mathrm{~b}$ & Methane monooxygenase & Methane & 509 & 145 & Sun $\&$ Wood (1996) \\
\hline
\end{tabular}

it has been shown that a range of aliphatic and chlorinated alkenes and epoxides serve as inducers for alkene monooxygenase and epoxidase expression in Xanthobacter Py2 (Ensign, 1996). The physiological substrates of the TCE-cooxidizing oxygenases are competitive substrates for the TCE degradation enzymes and some compounds are toxic, which may preclude their environmental use. To overcome these intrinsic obstacles of the wild-type strains, selection of strains exhibiting inducer-independent TCE degradation capabilities or the construction of recombinant Pseudomonas strains in which TCE-oxidizing enzymes are under the control of an alternative promoter have been performed. For example, B. cepacia G4PR 1 constitutively expressing toluene-2-monooxygenase has been derived from $B$. cepacia G4 (Shields \& Reagin, 1992) and Pseudomonas hybrid strains (JR1A::ipb and CBS-3::ipb) constitutively expressing isopropylbenzene dioxygenase have been constructed (Berendes et al., 1998).

In contrast to other strains degrading TCE, alkene monooxygenase-mediated TCE degradation by $R$. corallinus B-276 occurred in a growth-phase-dependent manner independent of inducer substrates, such as the physiological substrates of the alkene monooxygenase or chlorinated alkenes. Accordingly, glucose as carbon source led to TCE degradation rates comparable to those obtained with propene-grown cultures. To our knowledge, this is the first TCE-degrading wild-type strain neither requiring physiological substrates of oxygenases nor chlorinated alkenes to achieve expression of the TCE-oxidizing enzyme system. However, the presence of unknown inducers or repressors in NBG medium cannot be ruled out. A thorough understanding of how alkene monooxygenase is regulated will require the identification and characterization of regulatory genes, which are currently being performed.

Besides TCE, a number of other chlorinated compounds were degraded by NBG-grown cells of $R$. corallinus B276. All chlorinated alkenes tested were at least partially oxidized whereas chlorinated alkanes tested were not degraded. These results are consistent with known properties of the alkene monooxygenase enzyme system, which does not exhibit alkane hydroxylase activity. Propene-grown cells of Xanthobacter Py2 have also been shown not to degrade chlorinated alkanes (Ensign et al., 1992; Ensign, 1996). Although the substrate specificity of the alkene monooxygenases of $R$. corallinus B-276 and Xanthobacter Py2 was comparable with respect to chlorinated alkenes, there were significant differences in degradation efficiencies, for example 1,1dichloroethene was the poorest substrate for the alkene monooxygenase of Xanthobacter Py 2 among the chlorinated alkenes tested but this compound was more efficiently degraded by $R$. corallinus B-276 than TCE, trans-1,2-dichloroethene and 1,3-dichloropropene.

The apparent $K_{\mathrm{m}}$ and $V_{\max }$ values for TCE degradation by $R$. corallinus $\mathrm{B}-276$ were determined. Comparison of the kinetic parameters of NBG-grown R. corallinus B276 with those of propene-grown Xanthobacter Py2, phenol-grown $B$. cepacia G4, LB medium-grown $B$. cepacia G4PR1, phenol-grown $P$. mendocina KR1, toluene-grown P. putida F1 and methane-grown Methylosinus trichosporium $\mathrm{OB} 3 \mathrm{~b}$ revealed that the $V_{\max }$ value of $R$. corallinus B-276 was quite low and the $K_{m}$ value was at the highest level (Table 2). The kinetic parameters for propene indicate that propene is a much better substrate for the alkene monooxygenase than TCE. The applicability of $R$. corallinus B-276 for TCE degradation in the environment might be restricted by the low affinity and low degradation rates of the alkene monooxygenase, but the advantage of this enzyme system is that glucose-grown resting cells, which are easy to prepare, can be used for a TCE bioremediation process.

During our studies, we found that $R$. erythropolis $\mathrm{BD} 2$, which carries the linear plasmid pBD2 encoding an isopropylbenzene-degradation pathway (Dabrock et al., 1994), has the ability to grow on propene as a sole carbon and energy source. A spontaneous mutant strain $\mathrm{BD} 2.101$, which is $\mathrm{pBD} 2$-deficient, lost the ability to grow on propene (data not shown). These results indicate that the genes responsible for the propene catabolism of strain BD2 are also localized on the linear plasmid pBD2. However, no hybridization signal was detected with the plasmid pBD2 or PstI-digested total DNA with the probe of alkene monooxygenase genes from $R$. corallinus $\mathrm{B}-276$ (data not shown). This leads to the suggestion that the $R$. erythropolis $\mathrm{BD} 2$ genes responsible for the growth on propene differ from the 
alkene monooxygenase genes in $R$. corallinus $\mathrm{B}-276$ and might even encode an enzyme in a different family.

Southern hybridization of amo $A B C$ gencs with linear plasmid DNA of the short-chain-alkene-oxidizing strains revealed specific signals with the $260 \mathrm{~kb}$ linear plasmids of two propene-oxidizing $R$. ruber strains. These results suggest that the $R$. ruber strains carry linear plasmids encoding alkene monooxygenases which exhibit significant similaritics to the alkene monooxygenase of $R$. corallinus B-276. Taken together, our results strengthen the hypothesis that linear plasmids play a major role in acquiring novel catabolic capabilities by horizontal gene transfer between Rbodococcus species and therefore can be considered to be important tools in the evolution of biochemical pathways.

\section{ACKNOWLEDGEMENTS}

H.S. gratefully acknowledges support from the Japan Energy Co. during the stay in Göttingen. The work performed in Götringen was supported by the Deursche Forschungsgemeinschate and the Fonds der Chemischen lndustrie.

\section{REFERENCES}

Amoore, J. E. \& Hautala, E. (1983). Odor as an aid to chemical safety: odor threshold values compared with threshold limit values and volatilities for 214 industrial chemicals in air and warer dilution. I Appl Toxicol 3, 272-290.

Anand, R. (1986). Pulsed field gel electrophoresis: a technique for fractionating large DNA molccules. Trends Genet 2, 278-283.

Arciero, D., Vannelli, T., Logan, M. \& Hooper, A. B. (1989). Degradation of trichlorocthylene by the ammonia-oxidizing hactcrium Nitrosomonas europaea. Biochem Biophys Res Commun 159, 640-643.

Berendes, F., Sabarth, N., Averhoff, B. \& Gottschalk, G. (1998). Construction and use of an ipb DNA module to generaie Pseudomonas strains with constirutive trichloroethene and isopropylbenzene oxidation activity. Appl Entiron Microbiol 60, $855-860$.

Brusseau, G. A., Tsien, H.-C., Hanson, R. S. \& Wackett, L. P. (1990). Optimization of trichloroerhylene oxidation by methanotrophs and the use of a colorimetric assay to detect soluble methane monooxygenasc activity. Biodegradation 1, 19-29.

Claus, D., Lack, P. \& Neu, B. (1983). Deutsche Sammiung von Mikroorganismen und Zellkulturen Catalogte of Strains, 3rd edn. Braunschweig, Germany: Deursche Sammlung von Mikroorganismen und Zellkuleuren.

Dabrock, B., Riedel, J., Bertram, J. \& Gottschalk, G. (1992). lsopropylbenzene (cumene) - a new substrate for the isolation of trichlorocthene-degrading bacteria. Arch Microbiol 158, 9-13.

Dabrock, B., Keßeler, M., Averhoff, B. \& Gottschalk, G. (1994). Identification and characterization of a transmissible lincar plasmid from Rhodococas erythropolis BD2 that encodes isopropylhenzenc and trichloroethene carabolism. Appl Environ Microbiol 60, 853860 .

Ensign, S. A. (1996). Aliphatic and chlorinated alkenes and epoxides as inducers of alkene monooxygenase and epoxidase activitics in Xanthobacter strain Py2. Appl Fnviron Microbiol 62, 61-66.

Ensign, S. A., Hyman, M. R. \& Arp, D. J. (1992). Comerabolic degradacion of chlorinated alkenes by alkene monooxygenase in a propylene-grown Xanthobacter strain. Appl Eniron Microbiol $58,30.38-3046$.

Ensley, B. D. (1991). Biochemical diversity of trichloroethylene metabolism. Annu Ret Microbiol 45, 283-299.

Fox, B. G., Borneman, J. G., Wackett, L. P. \& Lipscomb, J. D. (1990). Haloalkene oxidation by the soluble methane monooxygenase from Methylosinus trichosporium (OB,3b: mechanistic and environmental implications. Biochemistry 29,6419 6427.

Furuhashi, K. (1992). Biological routes to optically acrive epoxides. In Chirality in Industry, pp. 167-186. Edited by A. N. Collins, G. N. Sheldrakc \& J. Crosby. Chichester \& New York: Wiley.

Furuhashi, K., Taoka, A., Uchida, S., Karube, I. \& Suzuki, S. (1981). Producrion of 1,2-cpoxyalkanes from 1-alkenes by Nocardia corallina B-276. Fur J Appl Microbiol Biotechnol 12, 39-45.

Gallagher, S. C., Cammack, R. \& Dalton, H. (1997). Alkene monooxygenase from Nocartia corallina B-276 is a member of the class of dinuclear iron proteins capable of stercospecific cpoxygenation reactions. Eur J Biochem 247, 635-641.

Gallagher, S. C., George, A. \& Dalton, H. (1998). Sequencealignment modelling and molecular docking studies of the epoxygenase component of alkene monooxygenase from Nocardia corallina B 276. Eur J Bioche'm 254, 480-489.

Harker, A. R. \& Kim, Y. (1990). Trichloroethylene degradation by two independent aromatic-degrading pathways in Alcaligenes eutrophus JMP134. Appl Environ Microbiol 56, 1179-1181.

Kaphammer, B., Kukor, J. J. \& Olsen, R. H. (1990). Cloning and characterization of a novel toluene degradative parhway from Pseudomonas pickettii PKO1. In Abstrats of the 90th Annual Meting of the American Society for Microbiology, abstract K145, p. 243. Washington, DC: Amcrican Socicty for Microbiology.

Kesseler, M., Dabbs, E. R., Averhoff, B. \& Gottschalk, G. (1996). Studies on the isopropylbenzene 2,3-dioxygenase and the 3isopropylcatcchol 2,3-dioxygenase genes encoded by the linear plasmid of Rbodococcus erythropolis BD2. Microbiology 142 . .3241-32.51.

Kim, Y., Ayoubi, P. \& Harker, A. R. (1996). Constitutive expression of the cloned phenol hydroxylase gene(s) from Alcaligenes eutrophus JMP134 and concomitane trichlorocthylene oxidation. Appl Environ Microbiol 62, 3227-3233.

Koh, S.C., Bowman, J. P. \& Sayler, G. S. (1993). Soluble methane monooxygenase production and trichloroethylene degradation by a type I methanotroph, Metbylomonas methanica 68-1. Appl Enuiron Microbiol 59, 960967.

Leahy, J. G., Byrne, A. M. \& Olsen, R. H. (1996). Comparison of factors influencing erichlorocthylene degradation by tolueneoxidizing hacteria. Appl Fnviron Microbiol 62, 82.5-83.3.

McClay, K., Streger, S. H. \& Steffan, R. J. (1995). Induction of toluene oxidation activicy in Pseudomonas mendocina KRI and Psendomonas sp. strain ENVPC5 by chlorinated solvents and alkanes. Appl Entiron Microbiol 61, 3479-3481.

Masai, E., Sugiyama, K., Iwashita, N., Shimizu, S., Hauschild, J. E., Hatta, T., Kimbara, K., Yano, K. \& Fukuda, M. (1997). The bphDEF meta-cleavage pathway genes involved in biphenyl/polychlorinated biphenyl degradation are located on a linear plasmid and separated from the initial bphACB genes in Rhodococcus sp. strain RHA1, Gene 187, 141-149.

Matthew, M. K., Hui, C.-F., Smith, C. L. \& Cantor, C. R. (1988). High resolution separation and accurate size determination in pulsed field gel electrophoresis of DNA. IV. The influence of DNA topology. Biochemistry 27, 9222-9226.

Miura, A. (1993). Purification and characterization of the alkene' 
monooxygenase from Nocardia corallina B-276. $\mathrm{PhD}$ thesis, University of Warwick.

Miura, A. \& Dalton, H. (1995). Purification and characterization of the alkene monooxygenase from Nocardia corallina $\mathrm{B}-276$. Biosci Biotechnol Biochem 59, 853-859.

Newman, L. M. \& Wackett, L. P. (1997). Trichloroethylene oxidation by purified toluene 2-monooxygenase: products, kinetics, and turnover-dependent inactivation. J Bacteriol 179, 90-96.

Oldenhuis, R., Vink, R. L. J. M., Janssen, D. B. \& Witholt, B. (1989). Degradation of chlorinated aliphatic hydrocarbons by Methylosinus trichosporium OB3b expressing soluble methane monooxygenase. Appl Environ Microbiol 55, 2819-2826.

Reij, M. W., Kieboom, J., de Bont, J. A. M. \& Hartmans, S. (1995). Continuous degradation of trichloroethylene by Xanthobacter sp. strain Py2 during growth on propene. Appl Environ Microbiol 61, 2936-2942.

Saeki, H. \& Furuhashi, K. (1994). Cloning and characterization of a Nocardia corallina B-276 gene cluster encoding alkene monooxygenase. J Ferment Bioeng 78, 399-406.

Sambrook, J., Fritsch, E. F. \& Maniatis, T. (1989). Molecular Cloning: a Laboratory Manual, 2nd edn. Cold Spring Harbor, NY: Cold Spring Harbor Laboratory.

Schmidt, K., Liaanen-Jensen, S. \& Schlegel, H. G. (1963). Die Carotinoide der Thiorhodaceae. Arch Mikrobiol 46, 117-126.

Shields, M. S. \& Reagin, M. J. (1992). Selection of a Pseudomonas cepacia strain constitutive for the degradation of trichloroethylene. Appl Environ Microbiol 58, 3977-3983.

Shieids, M. S., Montgomery, S. O., Chapman, P. J., Cuskej, S. M. \& Pritchard, P. H. (1989). Novel pathway of toluene catabolism in the trichloroethylene-degrading bacterium G4. Appl Environ Microbiol 55, 1624-1629.

Shingleton, J. T., Applegate, B. M., Nagel, A. C., Bienkowski, P. R. \& Sayler, G. S. (1998). Induction of the tod operon by trichloroethylene in Pseudomonas putida TVA8. Appl Environ Microbiol 64, 5049-5052.

Small, F. J. \& Ensign, S. A. (1997). Alkene monooxygenase from Xanthobacter strain Py2. J Biol Chem 272, 24913-24920.
Sun, A. K. \& Wood, T. K. (1996). Trichloroethylene degradation and mineralization by pseudomonads and Methylosinus trichosporium OB3b. Appl Microbiol Biotechnol 45, 248-256.

Tschech, A. \& Pfennig, N. (1984). Growth yield increase linked to caffeate reduction in Acetobacterium woodii. Arch Microbiol 137, 163-167.

Tsien, H.-C., Brusseau, G. A., Hanson, R. S. \& Wackett, L. P. (1989). Biodegradation of trichloroethylene by Methylosinus trichosporium OB3b. Appl Environ Microbiol 55, 3155-3161.

Vannelli, T., Logan, M., Arciero, D. M. \& Hooper, A. B. (1990). Degradation of halogenated aliphatic compounds by the ammonia-oxidizing bacterium Nitrosomonas europaea. Appl Environ Microbiol 56, 1169-1171.

Wackett, L. P. \& Gibson, D. T. (1988). Degradation of trichloroethylene by toluene dioxygenase in whole-cell studies with Pseudomonas putida F1. Appl Environ Microbiol 54, 1703-1708.

Wackett, L. P., Brusseau, G. A., Householder, S. R. \& Hanson, R. S. (1989). Survey of microbial oxygenases: trichloroethylene degradation by propane-oxidizing bacteria. Appl Environ Microbiol 55, 2960-2964.

Wilhelm, E., Battino, R. \& Wilcock, R. J. (1977). Low-pressure solubility of gases in liquid water. Chem Rev 77, 219-262.

Winter, R. B., Yen, K.-M. \& Ensley, B. D. (1989). Efficient degradation of trichloroethylene by a recombinant Escherichia coli. Bio/Technology 7, 282-285.

Yanisch-Perron, C., Vieira, J. \& Messing, J. (1985). Improved M13 phage cloning vectors and host stains: nucleotide sequences of the M13mp18 and pUC19 vectors. Gene 33, 103-119.

Zylstra, G. J., Wackett, L. P. \& Gibson, D. T. (1989). Trichloroethylene degradation by Escherichia coli containing the cloned Pseudomonas putida F1 toluene dioxygenase genes. Appl Environ Microbiol 55, 3162-3166.

Received 1 February 1999; revised 19 March 1999; accepted 29 March 1999. 